\title{
Machado de Assis e Silvio Romero: escravismo, "raça" e cientificismo em tempos de campanha abolicionista (década de 1880)
}

\author{
Alberto Luiz Schneider \\ Pontifícia Universidade Católica de São Paulo (PUG-SP) \\ São Paulo - São Paulo - Brasil
}

O objetivo deste artigo é explorar a historicidade e as desavenças em torno do abolicionismo e da presença da "raça negra" no Brasil em fins do século XIX, fundamentalmente na década de 1880, recortado nas obras de Machado de Assis (1839-1911) e Silvio Romero (1849-1914). Nesse período, os grandes debates públicos giravam em torno do fenômeno literário, razão pela qual optou-se por investigar o modo como o escravismo e o abolicionismo e o racismo científico aparecem nos textos do historiador e crítico literário Silvio Romero, bem como na literatura de Machado de Assis. Um e outro foram nomes de prestígio na República das Letras e viriam a ser sócios-fundadores da Academia Brasileira de Letras em 1897, embora apresentassem fundas divergências intelectuais e políticas, as quais o artigo busca investigar.

\section{Palavras-chave}

Sílvio Romero; Machado de Assis; História, literatura; abolicionismo, cientificismo, "raça negra".

* é Professor de História do Brasil da Pontifícia Universidade Católica de São Paulo - PUCSP. Doutor em História pela Universidade Estadual de Campinas - UNICAMP (2005), com Pós-Doutorado no King's College London (2008) e no Departamento de História da Universidade de São Paulo - USP (2011). Foi professor convidado na Tokyo University of Foreign Studies (2004-2007). Publicou o livro: Sílvio Romero, hermeneuta do Brasil (São Paulo: Annablume, 2005), além de diversos artigos no Brasil e no exterior. E-mail: alberto.ls@uol.com.br. 


\title{
Machado de Assis and Sílvio Romero: slavery, race and scientificism in times of abolitionist campaign $(1880$ s)
}

\author{
Alberto Luiz Schneider \\ Pontifícia Universidade Católica de São Paulo (PUC-SP) \\ São Paulo - São Paulo - Brasil
}

The purpose of this article is to explore the historicity and disagreements around the abolitionism and the presence of the "black race" in Brazil in the late nineteenth century, essentially in the 1880s, in the work of Machado de Assis (1839-1911) and Sílvio Romero (1849-1914). In that period, the great public debates revolved around the literary phenomenon, which is the reason why it was decided to investigate the way the slavery and the abolitionism and the scientific racism appear in the texts of the historian and literary critic Sílvio Romero, as well as in the literary production of Machado de Assis. Both of them were prestigious names in the Respublica litterarum and would become founding partners of the Academia Brasileira de Letras in 1897, despite deep intellectual and political differences, which this paper seeks to investigate.

Sílvio Romero; Machado de Assis; history, literature, abolitionism; scientificism, "black race". 


\section{Introdução}

O objetivo deste artigo é colocar em diálogo as obras de Machado de Assis (1839-1911) e Sílvio Romero (1851-1914) em perspectiva histórica, assunto já bastante explorado pela crítica. Aqui, no entanto, se pretende investigar, por meio de pesquisa dos textos dos autores em questão, escritos fundamentalmente na década de 1880, o modo como um e outro se posicionaram frente às questões relativas ao escravismo, ao abolicionismo e a presença negra em tempo de recepção dos discursos científico-racialistas. Trata-se de dois autores fortemente inscritos no cânone literário brasileiro. O crítico literário Silvio Romero e o escritor Machado de Assis, como sabemos, foram antagonistas em muitos sentidos. Esse artigo, no entanto, não pretende discutir as questões propriamente literárias, embora elas sejam importantes e estejam implicadas na discussão, tampouco se concentra nas sociabilidades letradas que os envolviam, ainda que tangencie o assunto.

O foco está na observação como Machado e Romero lidaram com agendas políticas e intelectuais interligadas, essencialmente o debate em torno do escravismo e da Abolição; e, conectado a isso, a recepção do ideário científico -racialista. As respostas foram múltiplas, marcadas por silêncios e narrativas.

As décadas de 1870 e sobretudo de 1880 foram profundamente marcadas pelas agudização das lutas políticas abolicionistas, como demonstrou com rigor a obra de Angela Alonso, Flores, Votos e Balas: O Movimento Abolicionista Brasileiro (1868-1888), embora as lutas sejam anteriores, como a trajetória do militante abolicionista Luiz Gama, estudado por Elciene Azevedo, sugere. Os escritores e intelectuais das últimas décadas do século XIX também se entregaram ao debate sobre os supostos inconvenientes da presença negra na formação brasileira. Embaladas pela recepção do pensamento científico-racialista, a herança africana e as mestiçagens foram objetos de intenso debate, marcados por profunda negrofobia. A discussão chegou também as artes plásticas. É bem conhecido o quadro A Redenção de Cam (1895), de Modesto Brocos y Gomes (1852-1936), pintor galego radicado no Rio de Janeiro, com passagem pela Academia Imperial de Belas Artes. No momento em que a igualdade jurídica estava em vias de alcançar a letra da lei, o discurso cientificista renovou e modernizou o racismo brasileiro, agora com tintas científico-biológicas. 


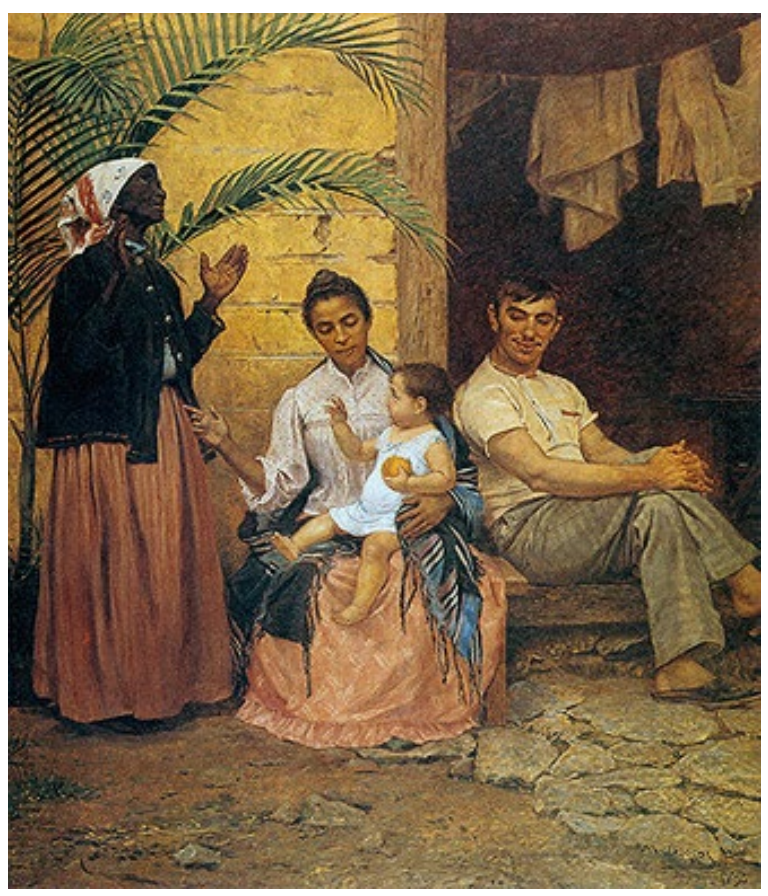

Modesto Brocos y Gomes. A redenção de Cam, 1895.

Sílvio Romero foi um intelectual da "geração de 1870", um tempo marcado pelo questionamento da ordem saquarema que vigorou quase ininterruptamente de 1848 a 1878. Os escritores e intelectuais dessa geração, por diferentes flancos, tenderam a confrontar os três pilares que sustentavam o Império: nas letras questionaram o indianismo romântico; nos costumes, o catolicismo hierárquico e o corte aristocrático; na estrutura produtiva, houve quem atacasse o latifúndio agroexportador e escravocrata. Não se trata aqui de aprofundar os meandros da "geração de 1870", mas de reconhecer a desagregação das estruturas políticas e mentais herdadas do Império. Era um momento de laicização, modernização e urbanização da vida brasileira, em que as noções de centro e periferia ou de atraso e modernidade entraram na agenda nacional (aliás, para não mais sair). A crise que culminou no fim da escravidão e da Monarquia, também implicou em uma profunda crise 
da cultura letrada. O romantismo indianista declinou junto com o Segundo Reinado, gerando a necessidade de expurgar seletivamente determinadas ideias (europeias), como a monarquia e o romantismo, por outras (não menos europeias), como as ciências, o realismo, o naturalismo ou o positivismo.

A partir da década de 1870 outra configuração histórica começaria a despontar. O fim do tráfico negreiro (1850) e da traumática Guerra do Paraguai (1864-1870) já insinuavam a crise da estabilidade imperial. Não demorou e a Monarquia e o escravismo entrariam em profunda crise que, ao fim e ao cabo, os levariam à queda. A imigração europeia começava a fluir, respondendo a políticas públicas, que não hesitaram usar recursos públicos para subvencionar a chegada de trabalhadores brancos . Os negros, o grande silêncio das cabeças letradas do Império, começavam a ser objeto de discussão. A consciência de haver um país habitado por vasta maioria negra e mestiça atormentava a sua elite intelectual. É o próprio Silvio Romero que nota o corte representado pela geração de 1870, em famoso discurso de recepção a Euclides da Cunha à Academia Brasileira, em 1906:

Até 1868 o catolicismo reinante não tinha sofrido nestas plagas o mais leve abalo; a filosofia espiritualista, católica, eclética a mais insignificante oposição; a autoridade das instituições monárquicas o menor ataque sério por qualquer classe do povo; a instituição servil e os direitos tradicionais do aristocratismo prático dos grandes proprietários a mais indireta opugnação; o romantismo, com seus doces, enganosos e encantadores cismares, a mais apagada desavença (...). Um bando de ideias novas esvoaçou sobre nós de todos os pontos do horizonte. (...) Positivismo, evolucionismo, cientificismo na poesia e no romance, folk-lore, novos processos de crítica e história literária, transformação da instituição do direito e da política, tudo então se agitou e o brado de alarma partiu da escola do Recife.

Angela Alonso destaca a relação entre os textos dos autores da geração de 1870 e suas múltiplas práticas de contestação política. O repertório dos "novos" contava com ideias cientificistas, positivistas, liberais, e, nas artes, experimentos realistas e naturalistas, adquiridas na Europa da segunda metade do século XIX e adaptadas ao Brasil de então. "Componentes deste repertório foram assimilados criteriosamente, conforme sua capacidade de elucidar a conjuntura brasileira e oferecer armas para a luta política 
". Seus membros compartilhavam a experiência de marginalização política, pois estavam alijados das restritas instituições imperiais. O cientificismo e as teorias racialistas expressavam, entre outras coisas, o dissenso em relação às estruturas mentais vigentes, mas também uma forma de modernizar a compreensão sobre a diferença e a desigualdade herdadas do passado escravocrata. Declinava o discurso católico hierárquico simbolizado nas instituições monárquicas e ascendiam doutrinas modernizadoras, próprios de um discurso laico, em geral republicano.

Com estas preocupações, Silvio Romero leu anacronicamente Gregório de Matos, ao ver no escritor soteropolitano do século XVII o despertar da consciência nacional por meio da fusão das três raças formadoras. Romero, leitor de Taine, estava interessado no peso do "meio", da "raça" e da "evolução histórica", mas também dos costumes e das tradições, a fim de explicar não apenas a literatura, mas o país. $\mathrm{O}$ tema da mestiçagem e da presença negra e indígena na formação brasileira mobilizou grande parte da obra do autor . Nesse momento, os abolicionistas - de José do Patrocínio (1853-1905) à Joaquim Nabuco (1849-1910), de Antônio Bento (1843-1898) à André Rebouças (1838-1898) - atacavam a escravidão, que resistia de modo mais feroz do que hoje se imagina.

Em texto de 1881 - o mesmo ano em que Machado de Assis lançou em livro Memórias Póstumas de Brás Cubas - Silvio Romero publicou Introdução à Literatura Brasileira, no qual discutiu questões como a "fisiologia do brasileiro" e a influência do "meio", com ênfase em considerações de ordem cultural, mas também e sobretudo, biológicas acerca dos povos que habitavam o Brasil: "[...] o sangue fica pouco estimulante; [...] não se arterializa [...] como nos climas frios, onde a respiração é mais enérgica ". Os conhecimentos científicos que inferiorizavam os povos não europeus foram recepcionados e adaptados às condições brasileiras. A eminência do fim da escravidão deveria mudar a "respiração" do país, tornando-a "mais enérgica", como parte da modernização, que deveria se adequar ao mercado livre de trabalho: 
Eis ao que ficou reduzida pelo clima da Índia a raça mais progressiva e inteligente da terra [a "raça" ariana]. Se o nosso céu não é tão déspota, não deixa de sê-lo até certo ponto. Conjuremos sempre por novas levas de imigrantes europeus a extenuação de nosso povo; [...] por meio de todos os grandes recursos da ciência.

Silvio Romero propunha "levas de imigrantes" a fim de modernizar o país. Mas o que pensava o autor sobre os negros? Lembremos que os intelectuais e escritores ligados à tradição romântica e ao Império silenciaram sobre a escravidão africana e a vasta presença negra no Brasil. O tema era constrangedor, sobre o qual prevalecia o silêncio, com poucas exceções, como a voz de Castro Alves (1847-1871). No entanto, a partir da virada antirromântica, pós 1870, da qual Romero fez parte, o escravismo e a presença africana tornaram-se objeto do debate político e intelectual. Romero, na sua História da Literatura brasileira (1888), não deixou de reconhecer a centralidade da presença da "raça negra":

A falta de documentos não quer dizer que o negro não tenha influído intelectualmente no Brasil; por uma indução geral e bem firmada devo concluir no sentido afirmativo.

A pobre raça escravizada não teve nunca o direito de entrar na história; seu trabalho intelectual foi anônimo, bem como seu trabalho fisico. Ainda mesmo em fatos altamente épicos, em fenômenos extraordinários, como o do Estado de Palmares, a história é anônima. Como se chamava o herói negro, o último Zumbi, que sucumbiu à frente dos seus nos Palmares? Ninguém sabe. É de justiça conquistar um lugar para o africano em nossa história.

Não deixa de ser surpreendente a defesa da importância dos negros na formação brasileira como um traço da nacionalidade, como parte da história e da cultura popular brasileira, embora o autor tenha aceitado a tese (científica) da inferioridade dos negros. Ainda na História da literatura brasileira, o autor reivindica de modo ainda mais explícito um lugar para os negros na genealogia da nação, ainda que numa posição evidentemente subordinada:

O negro é adaptável ao meio americano; é suscetível de aprender; não tem as desconfianças do índio; pode viver ao lado do branco, aliar-se a ele. Temos hoje muitos pretos que sabem ler e escrever; alguns formados em direito, medicina ou engenharia; alguns comerciantes ricos; outros jornalistas e oradores. Ao negro devemos muito mais do que ao índio; ele entra em larga parte em todas as manifestações de nossa atividade. Cruzou-se muito mais com o branco. 
De certo modo, a leitura de Silvio Romero quanto à participação dos negros na história e na cultura brasileira foi singular, ainda mais se pensarmos nas perspectivas científico-racialistas que o próprio Romero assumia. No entanto, não podemos perder de vista o conjunto e a historicidade do olhar romeriano. Os negros no Brasil estariam condenados a desaparecer ou ao menos a ver sua presença fortemente mitigada em função da imigração europeia, que adensaria demográfica e culturalmente a presença branca no país. Além dos europeus que aportavam naquele momento (e continuariam a aportar nas décadas seguintes em ainda maior número), somava-se a desejável miscigenação entre os imigrantes e os brasileiros formados na "mescla índio-áfrico -portuguesa". Imigração e a mestiçagem fariam a "forma branca prevalecer":

O mestiço é o produto fisiológico, étnico e histórico do Brasil; é a forma nova de nossa diferenciação nacional. Nossa psicologia popular é um produto desse estado inicial. Não quero dizer que constituiremos uma nação de mulatos; pois a forma branca prevalece e prevalecerá; quero dizer apenas que o europeu aliou-se aqui a outras raças, e desta união saiu o genuíno brasileiro, aquele que não se confunde mais com o português e sobre o qual repousa nosso futuro.

Ao passo que Romero propunha a imigração e a ciência como instrumentos capazes de colocar o país no caminho da modernização, Machado ironizava a ciência, como em $O$ alienista (1882). Enquanto Romero falava dos inconvenientes da população africana e seus descendentes mestiços, Machado, ao falar do país por meio da literatura, jamais propôs imigrantes, nem condenou o país pelos seus negros e mestiços, mas não deixou de falar sobre a escravidão. 


\section{Machado e a crítica à escravidão}

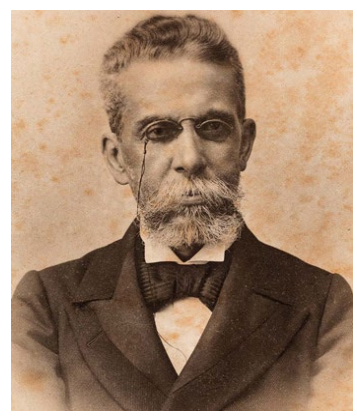

Machado de Assis

Como se sabe, a literatura de Machado de Assis recusou o estatuto científico das teorias racistas, ao qual destinou tenaz silêncio, só quebrado com mordazes ironias. Entre os escritores e intelectuais mais prestigiados do período, o Bruxo de Cosme Velho não foi o único a recusar o cientificismo racista, mas foi um dos poucos. Machado foi acusado de ter dado pouca atenção ao assunto, a começar por Silvio Romero. Mais que isso: foi acusado de empenhar-se no seu próprio branqueamento. Dados biográficos, como a condição de mulato e o casamento com a portuguesa Carolina Novaes, foram usados como prova da vontade do "mulato meridional" passar-se por "branco puro", como acusará Romero em tom belicoso e pouco elegante. Machado recusou, desde cedo, o gesto militante e a voz de autoridade. No entanto, há em sua obra espaço para agendas históricas e sociais, mas quase sempre nas entrelinhas, ainda que, vez ou outra, se possam encontrar notas explícitas, em particular na crítica. Em trecho de carta endereçada a José de Alencar (1829-1877), de fevereiro de 1868, Machado elogia Gonzaga, peça dramática de Castro Alves, escrita em tom fervorosamente abolicionista:

"Eu não podia, por exemplo, deixar de mencionar aqui a figura do preto Luiz. Em uma conspiração para a liberdade, era justo aventar a ideia da abolição. Luiz representa ao elemento escravo. Contudo o Sr. Castro Alves não deu exclusivamente a paixão da liberdade [...]. Luiz espera da revolução, antes da liberdade, a restituição da filha; é a primeira afirmação da personalidade humana; o cidadão virá depois. Por isso, quando no terceiro ato Luiz encontra a filha já cadáver, e prorrompe em exclamações e soluços, o coração chora com ele, e a memória, se a memória pode dominar a tais comoções, nos traz aos olhos a bela cena do rei Lear, carregando nos braços Cordélia morta. Quem os compara não vê nem o rei nem o escravo; vê o homem". 
Há muitas outras passagens que evidenciam um Machado sensível à causa da Abolição, mas muitas vezes envolta em discussões mais amplas em torno da condição humana. Sidney Chalhoub, em Machado de Assis, Historiador , empenhou-se em demonstrar um escritor que, por meio de contos, crônicas e romances retratou a incapacidade da classe senhorial em pensar o mundo, ou o Brasil da época, sem o trabalho escravo. Chalhoub desce até a biografia de Machado para mostrar que sua atuação como funcionário do Ministério da Agricultura serviu para ampliar o alcance da Lei do Ventre Livre (1871). O assunto já foi trabalhado por muitos autores , mas é importante registrar a presença de retratos da mentalidade senhorial nas obras de Machado de Assis. Nos contos O caso da vara, O espelho e Pai contra mãe, escritos após a Abolição, a escravidão é diretamente abordada. No entanto, para os limites desse texto, interessa investigar os anos finais do escravismo. Memórias Póstumas de Brás Cubas, publicado originalmente em 1880, em fascículos, nas páginas da Revista Brazileira, foi escrito em um momento de pleno combate entre escravocratas e abolicionistas, quando os primeiros ainda gozavam de força política e social.

É preciso notar que Memórias Póstumas de Brás Cubas (1880/1881) representou uma grande inovação na produção machadiana, construída justamente em momento de tensão com o cientificismo de Silvio Romero e outros "novos". Aliás, em artigo publicado na Revista Brazileira em $1^{\circ}$ de dezembro de 1879, intitulado "A nova geração", Machado já criticava a adesão irrestrita ao realismo, bem como abordagens extra literária, como os discursos científicos, garantissem à literatura a condição de portadoras de uma verdade universal. Machado quer desvincular o realismo e o cientificismo da ideia de verdade como fica evidente em seus textos na Revista Brazileira, em que se percebe a crítica à manipulação da percepção de verdade, bem como certos limites da capacidade reveladora da ciência. Machado, ao criticar a falta de estilo de Romero provavelmente aludia à presunção que a afetação científica garantisse a verdade.

Faltava-lhes estilo, que é uma grande lacuna nos escritos do Sr. Sílvio Romero; não me refiro às flores de ornamentação, à ginástica de palavras; refiro-me ao estilo, condição indispensável do escritor, indispensável à própria ciência (...). 
A recusa de Machado em relação ao realismo (e o naturalismo) guardam fortes laços com sua recusa ao cientificismo. Ele parece preocupado com a manipulação da ideia de verdade e de realidade. Daniela Magalhães da Silveira, ao estudar Papéis Avulsos (1882) nota que a retórica (da verdade) e o uso da ciência como razão explicativa caminhavam lado a lado: "O ofício de escritor de folhetins e organizador de livros permitia a Machado de Assis a elaboração de narrativas que discutiam o fazer literário e, por conseguinte, as práticas de dominação social que elegiam no discurso científico seus subsídios". Nesse sentido, a obra madura de Machado pode ser lida como uma resposta as pretensões objetivistas e universalistas. $\mathrm{O}$ cientificismo foi associado a cultura do fingimento, da afetação de erudição. Daniela Magid nota que:"

"O literato argumentava que o problema não era a realidade, mas sim o realismo; não eram as descobertas científicas, mas o uso que os novos poetas vinham fazendo da ciência, como fonte de onde colher nomes complexos para fazer seus textos parecerem eruditos, prescindindo do estilo literário. Machado de Assis considerava esse último aspecto o ponto fraco da obra de seu opositor, Sílvio Romero".

Para compreender as implicações de Memórias Póstumas concentremonos em Brás Cubas. O "defunto autor" viveu entre 1805 a 1869, quando o escravismo vicejava em todos os poros da sociedade brasileira. A personagem viveu os momentos mais dramáticos da história do País, como a crise regencial e as revoltas regionais, o tráfico ilegal de escravos, as lutas pelo fim do tráfico (1850), a Lei de Terras (1850) e a Questão Christie (1862). Foi um tempo de batalha política em torno da Lei do Ventre Livre (1871), conquistada apesar da resistência dos proprietários, bem como a crescente politização dos debates em torno da Escravidão, com o crescimento da agenda abolicionista. Em Memórias Póstumas, Machado descreve um escravocrata, como muitos outros de sua classe social, que não alcançou a "celebridade", nem foi "ministro", "mas coube-me a boa fortuna de não comprar o pão com o suor do meu rosto".

Brás Gubas encarna o ócio e o privilégio, em desalinho com a instituição de um ordenamento liberal que a retórica do progresso propunha, baseado no elogio do trabalho e do empreendimento. Trata-se, entre outras dimen- 
sões, de uma sátira da classe senhorial brasileira que aceita com entusiasmo novidades técnicas e teóricas vindas da Europa, mas empregadas como instrumentos de legitimação de prestígio e preservação do poder. Nos oito anos de "estudos" na Europa, Brás Cubas angariou o preparo necessário para "ornamentação, a fraseologia, a casca", aprendendo apenas o "liberalismo teórico e o romantismo prático". Ainda que longa a citação, vale a pena observar as palavras do narrador-defunto sobre si mesmo e seu gosto pela "nomeada", e pelo "amor da glória":

Essa ideia era nada menos que um medicamento sublime, um emplasto anti -hipocondríaco, destinado a aliviar nossa melancólica humanidade. Na petição de privilégio que então redigi, chamei a atenção do governo para esse resultado, verdadeiramente cristão. Todavia, não neguei aos amigos as vantagens pecuniárias que deviam resultar da distribuição de um produto de tamanhos e tão profundos efeitos. Agora, porém, que estou cá do outro lado da vida, posso confessar tudo: o que me influiu principalmente foi o gosto de ver impressas nos jornais, mostradores, folhetos, esquinas, e enfim nas caixinhas de remédio, estas três palavras: Emplasto Brás Cubas. Para que negá-lo? Eu tinha a paixão do arruído, do cartaz, do foguete de lágrimas. Talvez os modestos me arguam esse defeito; fio, porém, que esse talento me hão de reconhecer os hábeis. Assim, minha ideia trazia duas faces, como as medalhas, uma virada para o público, outra para mim. De um lado, filantropia e lucro; de outro lado, sede de nomeada. Digamos: - amor da glória.

Além do gosto aristocrático, do culto ao nome e ao prestígio, Machado de Assis chegará ao tema da Escravidão, inseparável da vida dos homens e das mulheres que habitavam os círculos do país de Brás Cubas. Quando criança, a personagem ganhara o apelido de "menino diabo", com a graça e simpatia do pai amoroso, que endossa a "divertida" mania de quebrar a cabeça de uma escrava que lhe nega mimos e doces, e de montar em Prudêncio - menino negro e escravo -, transformado em montaria do "menino diabo".

Prudêncio, um moleque de casa, era meu cavalo de todos os dias; punha as mãos no chão, recebia um cordel nos queixos, à guisa de freio, eu trepava-lhe ao dorso, com uma varinha na mão, fustigava-o, dava mil voltas a um e outro lado, e ele obedecia, - algumas vezes gemendo, - mas obedecia sem dizer palavra, ou, quando muito, um - "ai, nhônhô!"” -, ao que eu retorquia: - "Cala a boca, besta!". 
Lembremos que Brás Cubas nasceu na elite agrária, dependente da escravidão. Machado não entra nesse assunto, mas sabe que o leitor conhece a centralidade do escravismo. Tão central que o negro escravo é o cavalo (e brinquedo) daquela sociedade.

O "menino-diabo", ainda criança, talvez pouco antes da Independência, em uma festa dada pelo pai, escuta alguém dar a notícia sobre o tráfico de escravos, assunto corriqueiro para homens como o pai de

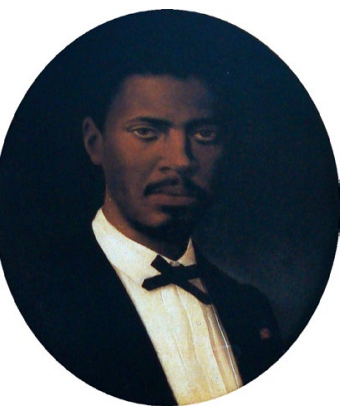

André Rebouças Brás Cubas.

[...] segundo cartas que recebera de Luanda, uma carta que o sobrinho lhe dizia ter já negociado cerca de quarenta cabeças, e outra carta em que... Trazia-as justamente na algibeira, mas não as podia ler naquela ocasião. $\mathrm{O}$ que afiançava é que podíamos contar, só nessa viagem, uns cento e vinte negros, pelo menos.

Os últimos anos do escravismo e do Império foram conturbados, mas de crescente força dos discursos abolicionistas e republicanos. Uma série de convergências e divergências marcaram ambos os movimentos. $\mathrm{O}$ que viria primeiro, a República ou a Abolição? Muitos dos integrantes da geração de 1870 associaram um e outro movimento, mas dividiam-se quanto às prioridades. Não há espaço, nem é o foco deste artigo aprofundar a questão, mas é importante salientar as clivagens entre os homens de 1870 e notar, como faz Maria Fernanda Lombardi Fernandes, que as bandeiras abolicionistas e republicanas não necessariamente foram carregadas em conjunto e muitas vezes estavam separadas:

Era plenamente possível ser republicano e defender, se não a Escravidão, a protelação da Abolição, ao mesmo tempo em que era possível defender o fim da Escravidão, sem mais delongas, e a manutenção da Monarquia. Várias posições intermediárias também eram possíveis. Isso gerava a cisão entre o grupo de contestadores em dezenas ou centenas de associações, clubes, organizações políticas ou de ação social etc. Em torno desses dois temas também eram construídas as alianças - temporárias ou definitivas - entre membros, a princípio, pertencentes a correntes antagônicas. 
Lembremos que Machado de Assis, como seu amigo Joaquim Nabuco (1849-1920) e o outro abolicionista importante, André Rebouças (1838-1898), foram monarquistas, ao passo que Silvio Romero foi republicano, bem como republicana foi grande parte da elite cafeicultora (escravocrata) do Oeste Paulista, como indica a fundação do Partido Republicano Paulista na Convenção de Itu em 1873. A simpatia de Machado à monarquia não o impediu de tratar do escravismo em suas obras, com sutileza e radicalidade, nem de retratar a elite brasileira oitocentista com severidade, como já demonstrou Roberto Schwartz e muitos outros estudiosos. Para este texto, no entanto, é fundamental observarmos a historicidade da crítica ao escravismo que comparece ao romance machadiano, sobretudo Memórias Póstumas de Brás Cubas. A intervenção literária de Machado, na década de 1880, fez parte do processo de deslegitimação do escravismo, bem como da crítica à coisificação dos cativos, comparáveis ao gado: "cerca de quarenta cabeças", refere-se ironicamente ao um conjunto de negros escravizados. A condição de mercadoria vendável dos trabalhadores cativos fica bem clara no debate entre Brás Gubas, a irmã Sabina e o cunhado Cotrim. Após a morte do pai dos Cubas, os herdeiros debatem a partilha dos bens, aí incluídos os escravos da família:

- Ora, mano, deixe-se dessas coisas, disse Sabina, erguendo-se do sofá; podemos arranjar tudo em boa amizade, e com lisura. Por exemplo, Cotrim não aceita os pretos, quer só o boleeiro de papai e o Paulo...

- O boleeiro não, acudi eu; fico com a sege e não hei de ir comprar outro.

- Bem; fico com o Paulo e o Prudêncio.

- O Prudêncio está livre.

- Livre?

- Há dois anos.

- Livre? Como seu pai arranjava estas coisas cá por casa, sem dar parte a ninguém! Está direito. Quanto à Prata... creio que não libertou a Prata?

Cotrim, o cunhado de Brás Cubas - que havia sido contrabandista de escravos - não gostava deles, mas não abria mão dos cativos, pois eram importantes em sua desarvorada luta pela ascensão social. Ele agia com rigor e violência contra os escravos, mas só os "perversos" e "fujões", chicoteando-os até arrancar-lhes sangue. Machado põe a acusação na boca dos inimigos de 
Cotrim, deixando ao leitor o arbítrio. Ficamos sabendo que o "gênero de negócio" que o cunhado atuava necessitava de "modos duros":

"Como era muito seco de maneiras tinha inimigos, que chegavam a acusá-lo de bárbaro. $\mathrm{O}$ único fato alegado neste particular era o de mandar com frequência escravos ao calabouço, donde eles desciam a escorrer sangue; mas, além de que ele só mandava os perversos e os fujões, ocorre que, tendo longamente contrabandeado escravos, habituara-se de certo modo ao trato um pouco mais duro que esse gênero de negócio requeria, e não se pode honestamente atribuir à índole original de um homem o que é puro efeito das relações sociais."

Machado de Assis, contudo, não foi um ativista da causa abolicionista - como eram seus contemporâneos André Rebouças, José do Patrocínio e Joaquim Nabuco ou Luís Gama (1830-1882) -, mas era um fino observador da vida brasileira, expressando-se pela literatura, o que não deixa de ser uma intervenção no mundo. John Gledson, ao tratar das relações entre Machado e a Abolição, observa que o escritor assumiu certo relativismo, pois, ainda que se libertassem os escravos, eles teriam de viver do trabalho em condições miseráveis. Machado, entre ironias e chistes, nota Gledson, chama à atenção do leitor algo importante:

Abolição não é um movimento da escuridão para a luz, mas a simples passagem de um relacionamento econômico e social opressivo para outro... libertando os escravos, não se faz mais do que libertá-los para o mercado de trabalho, no qual serão contratados e demitidos e, sem dúvida, receberão salários miseráveis.

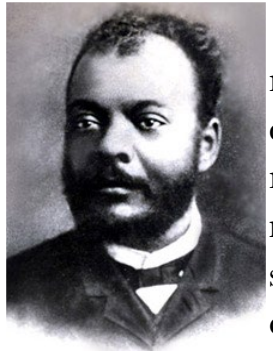

Machado, é certo, implicitamente recusara a retórica do progresso que assumiam os abolicionistas, para quem a Abolição redimiria o país. De fato, o escritor relativizava e mesmo desconfiava dos grandes engajamentos de seu tempo. Mas a causa abolicionista no Brasil da década de 1880 mobilizou corações e mentes, e o escritor - sempre cético e irônico -, nesse assunto talvez

José do Patrocínio 
tenha sido menos relativista do que supõe Gledson. Observemos a reflexão de Brás Cubas quando encontra Prudêncio, o menino negro transformado cavalo - agora livre e dono de um escravo, agindo como um senhor que de fato se tornara.

[...] era um preto que vergalhava outro na praça. $\mathrm{O}$ outro não se atrevia a fugir; gemia somente estas únicas palavras: - "Não, perdão, meu senhor; meu senhor, perdão"! Mas o primeiro não fazia caso, e, a cada súplica, respondia com uma vergalhada nova.

- Toma, diabo! Dizia ele; toma mais perdão, bêbado! - Meu senhor! Gemia o outro.

- Cala a boca, besta! Replicava o vergalho.

Parei, olhei... Justos céus! Quem havia de ser o vergalho? Nada menos que o meu moleque Prudêncio, - o que meu pai libertara alguns anos antes. Cheguei-me; ele deteve-se logo e pediu-me a bênção; perguntei-lhe se aquele preto era escravo dele. - É sim, nhonhô.

- Fez-te alguma coisa?

- É um vadio e um bêbado muito grande. Ainda hoje deixei ele na quitanda, enquanto eu ia lá embaixo na cidade, e ele deixou a quitanda para ir na venda beber.

- Está bom, perdoa-lhe, disse eu.

- Pois não, nhonhô. Nhonhô manda, não pede. Entra para casa, bêbado!

Saí do grupo, que me olhava espantado e cochichava as suas conjecturas. Segui caminho, a desfiar uma infinidade de reflexões, que sinto haver inteiramente perdido; aliás, seria matéria para um bom capítulo, e talvez alegre. Eu gosto dos capítulos alegres; é o meu fraco. Exteriormente, era torvo o episódio do Valongo; mas só exteriormente. Logo que meti mais dentro a faca do raciocínio achei-lhe um miolo gaiato, fino e até profundo. Era um modo que o Prudêncio tinha de se desfazer das pancadas recebidas, - transmitindo-as a outro. Eu, em criança, montava-o, punha-lhe um freio na boca, e desancava-o sem compaixão; ele gemia e sofria. Agora, porém, que era livre, dispunha de si mesmo, dos braços, das pernas, podia trabalhar, folgar, dormir, desagrilhoado da antiga condição, agora é que ele se desbancava: comprou um escravo, e ia-lhe pagando, com alto juro, as quantias que de mim recebera. Vejam as sutilezas do maroto!

A passagem é rica e caberia análise mais densa, mas o que o nos interessa aqui é evidenciar o quanto as Memórias Póstumas de Brás Cubas exibiram as perversidades da escravidão, concorrendo para deslegitimá-la. Machado não pensava em termos raciais, o que não é trivial em tempos científico-racialis- 
tas. Não é por que Prudêncio seja negro que não possa ser senhor e, como tal, violento. Negro, ex-escravo, Prudêncio se tornara um pequeno senhor, mas jamais se igualaria ao "nhonhô" Brás Cubas. Questão de classe e de cor. Prudêncio ao ver Brás Cubas pede bênção e imediatamente atende ao pedido do seu antigo senhor, pois "Nhonhô manda, não pede". É como se Machado quisesse dizer que um Prudêncio da vida, um negro livre, pode até se tornar um proprietário de escravo, possibilidade legal para qualquer homem livre do Império, mas nunca seria um Brás Cubas, ou seja, um homem branco, um grande proprietário, que andara a estudar pela Europa. Machado também sugere que um negro como Prudêncio pode até ser um pequeno escravocrata, mas os escravos, de Prudêncio ou de Brás Cubas, serão sempre negros. Se nem todos os negros e mulatos são escravos, todos os escravos são negros e mulatos.

A questão da escravidão como pano de fundo voltaria a aparecer em Dom Casmurro, romance de 1899, quando a Abolição já completara mais de uma década. No texto, Bentinho aponta para os escravos, em diálogo com Escobar, e narra a origem rural e escravocrata da família. Na passagem, fica claro que grande parte da renda da família provém do trabalho escravo. Não se trata de questão de somenos importância:

Contei-lhe o que sabia da vida dela e de meu pai. Escobar escutava atento, perguntando mais, pedindo explicações das passagens omissas ou só escuras. Quando eu lhe disse que não me lembrava nada da roça, tão pequenino viera, contou-me duas ou três reminiscências dos seus três anos de idade, ainda agora frescas. E não contávamos voltar à roça?

- Não, agora não voltamos mais. Olha aquele preto que ali vai passando, é de lá. Tomás!

\section{- Nhonhô!}

Estávamos na horta da minha casa, e o preto andava em serviço; chegou-se a nós e esperou.

- É casado, disse eu para Escobar. Maria onde está?

- Está socando milho, sim, senhor.

- Você ainda se lembra da roça, Tomás?

- Alembra, sim, senhor.

- Bem, vá-se embora. 
Mostrei outro, mais outro, e ainda outro, este Pedro, aquele José, aquele outro Damião...

- Todas as letras do alfabeto, interrompeu Escobar.

Com efeito, eram diferentes letras, e só então reparei nisto; apontei ainda outros escravos, alguns com os mesmos nomes, distinguindo-se por um apelido, ou da pessoa, como João Fulo, Maria Gorda, ou de nação como Pedro Benguela, Antônio Moçambique...

- E estão todos aqui em casa? Perguntou ele.

- Não, alguns andam ganhando na rua, outros estão alugados.

Não era possível ter todos em casa. Nem são todos da roça; a maior parte ficou lá.

- O que me admira é que Dona Glória se acostumasse logo a viver em casa da cidade, onde tudo é apertado; a de lá é naturalmente grande.

- Não sei, mas parece. Mamãe tem outras casas maiores que esta; diz, porém, que há de morrer aqui. As outras estão alugadas. Algumas são bem grandes, como a da Rua da Quitanda.

É preciso reconhecer a diferença de historicidade entre Dom Casmurro (1899) e Memórias Póstumas de Brás Cubas (1880/1881), escrita no início da dramática década de 1880, tempo de encarniçadas lutas entre abolicionistas e escravocratas. Em Memórias Póstumas, a cena doméstica é apresentada com absoluta naturalidade, como a reforçar a condição de coisa dos escravos. $\mathrm{O}$ efeito no leitor é o de chamar a atenção para uma naturalidade escravocrata que, naqueles anos, passara a ser alvo dos ataques abolicionistas. Angela Alonso nota que um dos grandes esforços dos abolicionistas foi justamente o de retratar os negros escravizados como pessoas, insistindo no que ela chamou de "retórica da compaixão", que servia poderosamente para deslegitimar as estruturas mentais do escravismo. A militância abolicionista dava-se sobretudo entre os grupos médios da população urbana do Rio de Janeiro e de outros centros urbanos, formada ao menos em parte por leitores de jornais e romances, frequentadores de teatro, precisamente o público dos escritores brasileiros da época. Machado de Assis, como sabemos, conferia ao leitor importância e atenção. Na cena a seguir, o narrador mostra mais um episódio da infância de Brás Cubas, onde os escravos comparecem à cena como parte do ambiente doméstico de uma família abastada e, naturalmente, escravocrata: 
Pedi em voz baixa o doce; enfim, bradei, berrei, bati com os pés. Meu pai, que seria capaz de me dar o sol, se lho exigisse, chamou um escravo para me servir o doce. A tia Emerenciana arrancara-me da cadeira e entregara-me a uma escrava, não obstante meus gritos e repelões.

Na cena, "a escrava" não tem nome, o que reforça a ideia de que a presença da escravidão não é trivial. Não se pode esquecer que Machado era amigo pessoal e interlocutor frequente de Joaquim Nabuco (1849-1910). É absolutamente impossível que o tema do trabalho escravo e da Abolição não comparecesse em suas tertúlias. Notemos que já no início de $O$ Abolicionismo obra de 1883, publicada só dois anos depois de Memórias Póstumas -, Nabuco chama atenção para a existência de uma espécie de linha de cor, como uma característica incontornável do escravismo moderno. De fato, somente os homens de "cor preta" foram sistematicamente escravizados no Novo Mundo por mais de três séculos:

A escravidão moderna repousa sobre uma base diversa da escravidão antiga: a cor preta. Ninguém pensa em reduzir homens brancos ao cativeiro: para este ficaram reservados tão somente os negros. Nós não somos um povo exclusivamente branco, e não devemos, portanto, admitir essa maldição pela cor ${ }^{1}$.

Justamente entre 1880 e 1881 os abolicionistas liderados por José do Patrocínio e André Rebouças organizaram no Rio de Janeiro uma série de conferências-concertos (que haveriam de continuar nos anos seguintes). Patrocínio e Machado eram mulatos, na linguagem do Século XIX, hoje dir-se-ia que eram negros. Os conferencistas atacavam os escravocratas, mencionavam a ineficácia da Lei do Ventre Livre, denunciavam os maus-tratos

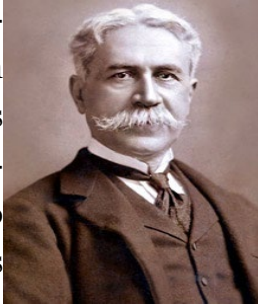

Joaquim Nabuco e defendiam a Abolição imediata sem indenização aos proprietários. Em alguns casos, os abolicionistas concediam cartas de alforria, com recursos arrecadados no evento, sempre revestido de tom patriótico, pois consideravam a abolição uma nova independência. Participavam da Associação Central

1 NABUCO, Joaquim. O Abolicionimo. Rio de Janeiro: Nova Fronteira, 1999. p. 24. 
Emancipadora (parte da Confederação Abolicionista)José do Patrocínio, André Rebouças, Vicente de Sousa, também negro, médico e professor de latim, além homens brancos, como João Clapp, todos fervorosamente defensores da causa. Na conferência, havia apresentações musicais e teatrais, o que garantia a casa cheia e dava sentido político aos eventos ${ }^{2}$. Joaquim Nabuco assumira uma posição mais institucional e tivera, na década de 1880, importante atuação internacional, capaz de obter apoio e contato ativo com importantes instituições internacionais, como a Anti-Slavery Society e a prestigiosa British and Foreign Anti Slavery Society ${ }^{3}$. Silvio Romero havia sido convidado para uma conferência abolicionista, mas não foi pretextando doença. Nesse momento, Romero e os abolicionistas viram-se enredados em uma violenta polêmica.

\section{A contenda entre Silvio Romero e os abolicionistas}

Para bem compreendermos oposição entre Silvio Romero e os abolicionistas - como José do Patrocínio, Vicente de Sousa e André Rebouças, ou mesmo Nabuco e Machado de Assis - é preciso compreender as polêmicas por eles protagonizadas em diversos veículos da imprensa carioca, no começo da década de 1880, em particular na Revista Brazileira, na Gazeta de Notícias, na Gazeta da Tarde e na Gazetinha. Ana Flávia Magalhães Pinto mapeou em detalhes a contenda ${ }^{4}$.

Romero, no já mencionado artigo da Revista Brazileira ataca não apenas o abolicionista branco e liberal, Joaquim Nabuco, o "diplomata vistoso, sedento de notoriedade fácil", mas também atacara os abolicionistas negros: "um ou outro sang-mêlé transformado de chofre em vidente e diretor da opinião bra-

2 ALONSO, Angela. Op. Cit., 2016, p. 113-151.

3 Sobre o assunto, ver: ALONSO, Angela: "Joaquim Nabuco e os abolicionistas britânicos. Correspondência, 1880-1905”. Estudos Avançados. Vol. 23, No. 65, São Paulo, 2009.

4 Sobre o assunto, ver: PINTO, Ana Flávia Magalhães. Fortes laços em linhas rotas: literatos negros, racismo e cidadania na segunda metade do Século XIX. Tese de Doutorado em História. IFGH / Unicamp. Campinas, 2014. pp. 85-111. A historiadora retoma a questão em capítulo de livro: "José do Patrocínio: abolição, racismo e uma pedra no caminho chamada Sílvio Romero". In: CHALHOUB. Sidney; PINTO, Ana Flávia Magalhães. (Org.). Pensadores negros - pensadoras negras; Brasil, séculos XIX e XX. Rio de Janeiro; Belo Horizonte: MC\&G Editorial; Editora Fino Traço, 2016, p. 105-127. 
sileira"'. Vicente de Sousa, um dos sang-mêle, acusou Romero de "inventar distinções de raças; a promover a cizânia na família brasileira, a procurarem inocentar seu egoísmo nefando, seu parasitismo insaciável, mentindo que são de raça ariana e que têm o direito de explorar indefinidamente a

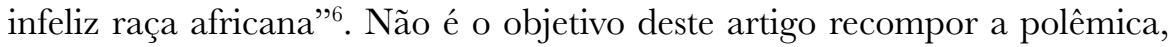
mas vale notar que Sílvio Romero iniciou uma série intitulada "De uma cajadada dois coelhos", na Gazetinha, em fevereiro de 1881. No texto, referindo-se a Patrocínio e a Vicente - dois homens negros, letrados e ativistas da causa abolicionista - Romero afirma: São "uns zulus estonteados da baixa demagogia"; "dois míseros canalhas, insensatos, sem critérios, que fazem da vida de atassalhar a todos, em trôpegas arengas que tresandam nauseabundo bodum negro!"; "dois capangas das letras que caíram sobre mim com suas navalhas afiadas" ". Para além da virulência, é importante notar que Romero está preocupado com o país e não com os negros: "Como fazer da emancipação dos escravos no Brasil uma questão de privilégios de negros, quando é certo que uma grande parte dos nossos escravos são descendentes de caboclos, são mamelucos, são cafuzos, e outros são pardos, e mestiços claros, e muitos quase brancos?". Romero, para não deixar dúvidas de sua negrofobia, associa José do Patrocínio ao "Demônio Familiar", peça de José de Alencar (1857), em que o moleque Pedro, negro mentiroso que traíra a confiança de seu senhor que, para puni-lo, acaba por conceder-lhe a liberdade ${ }^{9}$.

Convém relembrar que em 1880, a Revista Brazileira publicara em forma de folhetim Memórias Póstumas de Brás Cubas, de Machado de Assis, talvez o maior desafeto de Romero, um intelectual que se apresentava como aboli-

5 ROMERO, Silvio. "A questão do dia: a emancipação dos escravos". Revista Brazileira, ano 2, tomo 7, janeiro de 1881, Rio de Janeiro: N. Midosi Editor, 1881, p. 192.

${ }^{6}$ Gazeta da Tarde, 7 de fevereiro de 1881, p. 1-2.

7 Aqui me valho da tese de Ana Flavia Magalhães Pinto. Não me foi possível consultar diretamente a Gazetinha. PINTO, Ana Flávia Magalhães. Fortes laços em linhas rotas: literatos negros, racismo e cidadania na segunda metade do Século XIX. Tese de Doutorado em História. IFCH / Unicamp. Campinas, 2014.p. 102.

8 PINTO, Ana Flávia Magalhães. Fortes laços em linhas rotas: literatos negros, racismo e cidadania na segunda metade do Século XIX. Tese de Doutorado em História. IFCH / Unicamp. Campinas, 2014. p. 102.

9 A bibliografia sobre o assunto é extensa. Para uma introdução ao assunto ver: TRINDADE, Joyce Nathália de Souza. Fosé de Alencar e a escravidão: necessidade nacional e benfeitoria senhorial. Dissertação de Mestrado. Programa de Pós-Graduação em Ciências Sociais da UNIFESP, 2014. 
cionista. Alguns meses depois, no entanto, em fevereiro de 1881, Romero publicou, na mesma Revista, o artigo intitulado A questão do dia - a emancipação dos escravos. No texto, ele definiu a natureza de seu abolicionismo:

Quero a libertação dos escravos pelo meio prático de uma reductio ad absurdum da escravidão, sem que para isto se lhe marque um prazo; porque esta ideia foi repelida, e sem que seja necessário inverter a história de nossa civilização, que é uma civilização fundada pelos brancos e não inventada pelos negros. Não exijo destes que renunciem e posterguem a sua raça, mas deixem aos brancos o direito de também defenderem a sua. Quero a libertação como o resultado de uma transformação orgânica da sociedade, e não como um produto das declamações sem alvo do Sr. Nabuco, ou uma inversão das teorias negristas ${ }^{10}$; quero-a, como a devem querer aqui os representantes do espírito civilizador europeu ${ }^{11}$.

No texto, Romero evita aderir politicamente ao abolicionismo. Naquele momento, os grandes proprietários e escravocratas, que haviam sido contrários à Lei do Ventre Livre (1871), agora se agarravam a ela, a fim de evitar novas reformas. Romero também pensava assim: "depois da lei de 28 de setembro de 1871, a escravidão é um fenômeno mórbido, uma instituição que vai morrer, uma árvore daninha a que se cortaram as raízes ${ }^{12}$. Para ele, o caminho para a emancipação dos escravos deveria ocorrer sem intervenções do Estado, como queriam os abolicionistas, mas sim pela própria dinâmica econômica.

O melhor meio de acabar com a escravidão não é formular projetos absurdos e combinações legislativas engenhosas. O melhor meio de acabá-la é cerceá-la, pô-la em estado de sítio, estabelecer com ela a concorrência, torná-la inútil, e depois impossível. É fazer crescer a seu lado o trabalho livre, mais fecundo, e depois mais fácil, mais barato; é, em uma palavra, matá-la economicamente. Aquele órgão se atrofiará por falta de função. Não será preciso, portanto, pedir ao governo que decrete leis contra a escravidão ${ }^{13}$.

10 Grifo nosso.

11 ROMERO, Silvio. "A questão do dia - a emancipação dos escravos". Rio de Janeiro, Revista Brasileira, ano 2, tomo, janeiro de 1881, p. 203.

12 Idem, p. 192.

13 ROMERO, Silvio. Op. Cit., 1881, p. 196. 
Sílvio Romero assumiu uma perspectiva liberal, na qual a Abolição teria de vir, mas não como fruto de uma intervenção político estatal, e sim da dinâmica modernizadora do processo produtivo, de um modo "orgânico". A ideia de que as sociedades emulavam organismos vivos foi importantíssima na segunda metade do século $\mathrm{XIX}^{14}$. Fundamentado no liberalismo organicista, cientificista e raciológico, de fundo spenceriano, Romero afirma: "deixem aos brancos o direito de também defenderem a sua civilização $15 "$. Célia Maria Marinho de Azevedo observa que a convivência e mesmo a convergência entre o liberalismo e o cientificismo de fundo racista foi comum no Brasil de fins do Século XIX ${ }^{16}$.

A acusação de "escravocrata" perpetrada por José do Patrocínio tem íntima relação com as posições de Sílvio Romero quanto a sua interpretação acerca dos negros como "raça inferior". Ainda no longo artigo de 1881, na $R e$ vista Brazileira, Romero defendia que o Estado jamais extinguisse a Escravidão, porém argumentava em defesa do uso de fundos públicos para comprar o maior número possível de manumissões. Como já se observou, a sensibilidade liberal e conservadora de Romero o fazia respeitoso quanto ao direito de propriedade e defensor de um caminho gradual rumo ao trabalho livre, sensível aos interesses dos proprietários. Além disso, suas posições teóricas, signatárias de um pensamento científico-racialista, o levou a considerações abertamente racistas, posições que certamente chocaram José do Patrocínio e André Rebouças.

Não há exemplo de uma civilização negra. A única civilização africana, a do Egito, era branca, do ramo cuschitosemita [...]. A África esteve desde a mais remota antiguidade em contacto com os egípcios, persas, gregos, romanos, fe-

14 Sobre o assunto, ver HAWKINS, Mike. Social Darwinism in European and American Thought 18601945 - Nature as a Model and Nature as a Threat. Cambridge: Cambridge University Press, 1998.

${ }^{15}$ A passagem a seguir, de 1888, é representativa do viés cientificista de Romero: "A hereditariedade representa os elementos estáveis, estáticos, as energias das raças, os predicados fundamentais dos povos; é o lado nacional das literaturas. A adaptação exprime os elementos móveis, dinâmicos e genéticos, transmissíveis de povo a povo; é a face geral, universal da literatura. São duas forças que se cruzam, ambas indispensáveis, ambos produtos naturais do meio físico e social" (ROMERO. História da Literatura Brasileira. Tomo 1. Op. cit., p. 55. Apud SCHNEIDER, Alberto Luiz. Sílvio Romero, hermeneuta do Brasil. São Paulo: Annablume, 2005. p. 41.

${ }^{16}$ AZEVEDO, Celia Maria Marinho de. Onda negra, medo branco. São Paulo: Annablume, 2015. p. 55. 
nícios, cários e árabes, e o negro nunca chegou a civilizar-se! Há quatro séculos está em contacto com os modernos povos europeus e continua nas trevas ${ }^{17}$.

Sílvio Romero, para quem “o Brasil não é, não deve ser, o Haiti” insistia na inferioridade dos negros e cita, como voz de autoridade, o naturalista britânico Thomas Henry Huxley, que se apresentava como defensor da teoria da evolução de Darwin.

O negro é um ponto de vista vencido na escala etnográfica, e o Brasil não é, não deve ser, o Haiti. Eu não sei se os nossos publicistas de cor terão a veleidade de suporem-se mais ilustrados, mais lúcidos, mais desprendidos de prejuízo do que o ilustre naturalista Huxley. [...]

Pode ser absolutamente certo, diz Huxley, que alguns negros sejam superiores a alguns brancos; mas nenhum homem de bom senso, bem esclarecido sobre os fatos, poderá crer que em geral o negro valha tanto quanto o branco e muito menos seja-lhe superior. E se assim é, torna-se impossível acreditar que logo que sejam afastadas todas as incapacidades civis, desde que a carreira lhes seja aberta e que não sejam nem oprimidos nem favorecidos, nossos irmãos prognáticos possam lutar com vantagem com os seus irmãos melhor favorecidos de cérebro. Não só os irmãos negros não poderão, pois, chegar aos mais altos lugares da hierarquia estabelecida pela civilização, ainda que não seja necessário confiná-los lá para a última classe ${ }^{18}$.

A comparação com o Haiti é um velho topos Oitocentista. O medo de uma suposta haitinização, no caso de Romero, é menos o temor de uma possível rebelião escrava ou negra, e mais de uma eventual africanização da população brasileira, razão pela qual defendia a imigração europeia. Ao invés de africanizar-se como o Haiti, o Brasil deveria orientar-se no sentido de uma civilização branca e moderna. André Rebouças, em seu diário pessoal, registrou a crítica de José do Patrocínio a Sílvio Romero de modo breve e contundente: "Conflito com o escravocrata Sílvio Romero. As resistências dos escravocratas se acentuam ${ }^{19}$ '. O que as poucas palavras de Rebouças

\footnotetext{
17 ROMERO, Sílvio. Op. Cit., 1881, p. 199.

${ }^{18}$ Idem, p. 197-198.

19 REBOUÇAS, André. Diários e Notas Autobiográficas. Rio de Janeiro:José Olympio, 1938. p. 293. Sobre Rebouças, ver: CARVALHO, Maria Alice Rezende de. O quinto século, André Rebouças e a construção
} 
insinuam, talvez involuntariamente, é que nos anos de 1880 vivia-se uma modernização da negrofobia. Na medida em que a escravidão dava sinais inequívocos de esgotamento, perdendo legitimidade e viabilidade política, surgia uma nova forma de inferiorização dos negros pela via do discurso cientificista, mas também por meio da retórica do progresso e de um nacionalismo mestiço e embranquecedor, fundado no topos dos três povos, que Gilberto Freyre haveria de dar continuidade nos anos de $1930^{20}$.

Romero é um exemplo de um autor (timidamente) antiescravista cujos argumentos liberais e raciais confluíram para elaboração de um discurso segundo o qual a escravidão é economicamente irracional e atrasada. Foi com um arsenal teórico e político fundado na retórica do progresso, no nacionalismo e no cientificismo racista, que Romero interpretou a presença negra no Brasil. Discurso diferente de Joaquim Nabuco que não falara em "raça", mas em "cor". E, como sabemos, muito diferente de Machado de Assis, que jamais cedeu ao discurso científico-racialista.

No artigo da Revista Brazileira (1881) Romero utiliza uma expressão peculiar: "teorias negristas". Não se pode saber o que Romero pretendia dizer, mas sabermos que alguns dos principais líderes abolicionistas eram negros, como José do Patrocínio, André Rebouças e Vicente de Sousa. O outro líder abolicionista de relevo era o amigo de Machado de Assis, Joaquim Nabuco - filho do Senador liberal e Ministro da Justiça do Império, Nabuco de Araújo. Além de pleitearem o fim imediato da escravidão sem indenização aos proprietários, Rebouças, um dos "negristas", ainda falava em "democracia rural" em contestação ao latifúndio ${ }^{21}$. Patrocínio, outro "negrista", era mais belicoso e loquaz, politicamente próximo de Rebouças, porém mais radical.

do Brasil. Rio de Janeiro: Revan / Iuperj, 1998; SANTOS, Sydney dos. André Rebouças e seu tempo. Rio de Janeiro: Vozes 1985; TRINDADE, Alexandro Dantas. André Rebouças: da Engenharia Civil à Engenharia Social. Tese (Doutorado em Ciências Sociais). Campinas/SP: IFCH-UNICAMP, 2004.

${ }^{20}$ Sobre as relações entre Silvio Romero e Gilberto Freyre, ver SCHNEIDER, Alberto Luiz. "Gilberto Freyre, leitor de Silvio Romero". In Sílvio Romero, hermeneuta do Brasil... Op. Cit., p. 221-245.

${ }^{21}$ PESSANHA, Andréa Santos da Silva. "Pela palavra e pela imprensa: André Rebouças e propostas sociais para o Brasil do final do XIX". XXVII Simpósio Nacional da ANPUH: conhecimento histórico e diálogo social. Natal, 2013; MATTOS, Hebe. "André Rebouças e o Pós-abolição: entre a África e o Brasil (1888-1898)". XXVII Simpósio Nacional da ANPUH: conhecimento histórico e diálogo social. Natal, 2013 
Patrocínio dirigia-se menos às instituições e mais ao público, diretamente, por meio da Gazeta da Tarde, o jornal abolicionista, e mais tarde, via o $\mathrm{Ci}^{-}$ dade do Rio, de onde desancava o escravismo e os escravocratas ${ }^{22}$. É possível observar a maneira com que Romero se refere a Nabuco e dos "sangmêles" Patrocínio e Rebouças:

Quem já não vê que a questão [da emancipação dos escravos] passou de seu momento agudo sem que nada se haja resolvido, sem que outra coisa tenhamos apreciado além das coquetices do pedantocrata Joaquim Nabuco e das declamações ingênuas e inofensivas de um ou outro sangmêle transformado de chofre em vidente e diretor da opinião brasileira ${ }^{23}$ ?

O "pedantocrata" Joaquim Nabuco, até onde a pesquisa alcançou, não reagiu, mas o "sangmêle ${ }^{24 "}$ "José do Patrocínio respondeu à altura de Romero. Em artigo na Gazeta de Notícias acusou Sílvio Romero de "teuto maníaco de Sergipe", "Spencer de cabeça chata", "sectário de um materialismo energúmeno", "lacaio", "canalha" e "escravocrata ${ }^{25} "$. A ira de Patrocínio é compreensível, mas, a rigor, Romero não era um "escravocrata" em sentido estrito. Era, antes, um liberal spenceriano (portanto cientificista, racialista e mesmo racista), portador de sensibilidade conservadora quanto a esta agenda, ao ponto de atacar os abolicionistas justamente quando o escravismo se encontrava sob forte

${ }_{22}$ ALONSO, Ângela. Op. Cit., 2016, p. 85-112.

23 ROMERO, Sílvio. Op. Cit., 1881, p. 192.

24 A expressão francesa "Sang mêlele" significa "sangue misturado" e era portadora de alto teor pejorativo. Além do peso histórico do escravismo e do racismo, somava-se naqueles anos a penetração do moderno discurso científico-racialista. Arthur de Gobineau (1816-1882), que fora nomeado embaixador da França no Rio de Janeiro em 1869, havia escrito o Essai sur l'inégalité des races humaine (1853-55). Para ele, a mistura de "raças" levaria a degeneração. Gobineau insistia que o destino do Brasil estava definido e era altamente negativo. Apenas imigração europeia poderia remediar o quadro; (ver: SANTOS, Ricardo Alexandre. "A extinção dos brasileiros segundo o conde Gobineau". Revista Brasileira de História da Ciência, Rio de Janeiro, v. 6, n. 1, p. 21-34, jan | jun 2013). Silvio Romero e outros intelectuais brasileiros conheciam a obra de Gobineau. Usar a expressão Sang mêlể, em francês, era evidentemente um instrumento de ataque aos abolicionistas negros. José do Patrocínio e André Rebouças era negros.

${ }^{25}$ Gazeta de Notícias, de 07 de fevereiro de 1881. A polêmica repercutiu por todo Brasil e republicado por diferentes jornais, inclusive $O$ Libertador, de Fortaleza e, possivelmente, em outros jornais. 
ataque. Em termos políticos, tratava-se de uma posição de algum modo simpática aos escravocratas, o que torna a acusação de Patrocínio compreensível.

Em Estudos sobre a poesia popular do Brasil, livro publicado em 1880, Romero havia defendido a Abolição da escravidão, o que deve ter contribuído para ser convidado a dar uma conferência abolicionista (que por fim negara). $\mathrm{O}$ entusiasmo de Romero estava noutro lugar. Ele se colocava fortemente em defesa de "civilização" de matriz lusitana, mestiça, mas embranquecida (e que deveria embranquecer muito mais no futuro). Era fundamental viabilizar o progresso, o que passava por civilizar "os índios que restam" e emancipar os "ignorantes" cativos.

O nosso dever de brasileiros, de filhos dos três povos que nos entregaram o país descoberto, conhecido, povoado, autonômico e livre; cumpramos o nosso dever para com aqueles que nos amamentaram, isto é, honremos, por nossa grandeza, os portugueses; porque devemos enxergar neles, antes de tudo, os concidadãos do Gama, os compatriotas de Camões; civilizemos os índios que restam; porque devemos ver neles os nossos amáveis Pelasgos, perseguidos pela fortuna; libertemos os negros; porque os devemos considerar os desafortunados que nos ajudaram a ter fortuna; os cativos que nos auxiliaram na conquista da liberdade; os ignorantes que nos facilitaram a posse da civilização, e hoje nos oferecem o ensejo de praticarmos um ato nobre: - a emancipação dos escravos ${ }^{26}$.

Machado de Assis não tomou parte nos comícios abolicionistas. Mas, diferentemente de Romero, prosseguia produzindo sua contundente literatura. Em 1882, o escritor publicou Papéis avulsos, livro de contos em que se encontra $O$ Espelho: esboço de uma teoria da alma humana. Enquanto o discurso senhorial ligava os escravos e os negros à indolência, à promiscuidade e à selvageria, apresentando os próprios senhores como sujeitos dotados de moralidade e civilidade superior, Machado, ao contrário, constrói um personagem como Jacobino. Trata-se de um rapaz que, ao que tudo indica, era branco e de origem social modesta. Mas a promoção ao posto de Alferes da Guarda Nacional altera sua condição. Na fazenda da tia - uma senhora escravista - o jovem Jacobino deixa de ser chamado pelo nome, de acordo com ordens da

${ }^{26}$ ROMERO, Sílvio. Estudos sobre a poesia popular do Brasil. 2. ed. Petrópolis/RJ: Editora Vozes, 1977. p. 272. [1 ${ }^{\mathrm{a}}$ ed. 1880$]$ 
família. É o título que passa a identificar o sujeito, acima do próprio nome. Os escravos foram obrigados a tratá-lo por "senhor Alferes". Um dia, no entanto, na ausência da tia, os escravos abandonam a fazenda e o Alferes vêse privado não só do trabalho dos escravos, mas, também, da reverência que eles estavam obrigados a prestar-lhe.

Achei-me só, sem mais ninguém, entre quatro paredes [...]. Nenhum fôlego humano. [...] ninguém, um molequinho que fosse. Gatos e galinhas tão-somente, um par de mulas, que filosofavam a vida, sacudindo as moscas, e três bois [...] nenhum ente humano. Pareceu-lhes que isto era melhor do que ter morrido? Era pior ${ }^{27}$.

Sem os escravos para sustentar a identidade de um homem superior, o Jacobino não se encontra no espelho. Sem escravos, a ordem escravocrata sofre séria avaria. Sem eles, desaparece o poder e prestígio proporcionado aos proprietários, ferindo o que Sidney Chalhoub chamou de "ideologia senhorial"28".

\section{Modernizando a diferença}

Para refletirmos com rigor histórico sobre o Brasil do último quartel do Oitocentos, período que corresponde à grande parte da produção de Sílvio Romero e de Machado de Assis, precisamos notar que escravos e negros não são sinônimos, inclusive em termos demográficos. Já no Censo de 1872, os escravos representavam apenas $15,24 \%$ da população brasileira, de quase 10 milhões de habitantes. Ainda de acordo com o Censo, a população branca do Império era de $38,1 \%$, o que indica uma vasta gama de negros e mestiços livres. Em outras palavras, em torno de 58\% dos habitantes do Brasil de então eram "pretos" (como André Rebouças e Vicente de Sousa) e "pardos" (como José do Patrocínio e Machado de Assis).

No começo dos anos de 1880, intelectuais e escritores como Silvio Romero e Machado de Assis sabiam perfeitamente que a escravidão era institui-

\footnotetext{
${ }^{27}$ ASSIS, Machado de; COUTINHO, Afrânio (org). "O Espelho". In: Machado de Assis - obra completa em três volumes. Vol II. Rio de Janeiro: Nova Aguilar, 1994. p. 349.

${ }^{28}$ CHALHOUB, Sidney. Machado de Assis, Historiador... Op. Cit., 2003.
} 
ção em crise terminal. Se o instituto legal do escravismo, bem ou mal, estava prestes a ser destruído, a vasta presença de negros e mestiços na população brasileira era uma realidade inescapável ${ }^{29}$. Em outras palavras, a dinâmica que opunha senhor e escravo lentamente ia cedendo lugar a outra: a de brancos e negros, como se pode ser observar nas palavras do próprio Sílvio Romero, justamente em 1888, ano da abolição no Brasil.

A História do Brasil, como deve ser hoje compreendida, não é, conforme se julgava antigamente e era repetida pelos entusiastas lusos, a história exclusiva dos portugueses na América. Não é também, como quis supor o romanticismo, a história dos tupis, ou, segundo o sonho de alguns representantes do africanismo entre nós, a dos negros em o Novo Mundo. É antes a história da formação de um tipo novo pela ação de cinco fatores, formação sextiária, em que predomina a mestiçagem ${ }^{30}$.

Na passagem não há referência ao escravismo ou qualquer outro tipo de formação social, política ou econômica, mas seu evolucionismo organicista falará em "raças" e "sub-raças". No trecho aparecem "lusos", "tupis", "negros" e "mestiços". A desigualdade e a diferença não estavam mais no estatuto legal do escravo, mas sim, na "raça". A desigualdade e a diferença não vinham mais da velha ordem escravocrata, mas da moderna ciência (a mesma ciência que Machado recusara). Para Romero, "a literatura rege-se pela lei do desenvolvimento à maneira das formações biológicas. Ainda como as criações biológicas, ela tem a sua luta pela existência, onde as ideias mais fracas são devoradas pelas mais fortes ${ }^{31}$ ”. Se Romero não gastou maiores esforços em atacar o escravismo, embora se dissesse abolicionista, escreveria sobre os negros e gastaria longas páginas versando sobre os mestiços e a mestiçagem, bem como os novos personagens da vida brasileira: os imigrantes. Não é a proposta deste texto oferecer uma leitura global do pensamento de

\footnotetext{
${ }^{29}$ IBGE. Censo demográfico de 1872. Disponível em: < http://biblioteca.ibge.gov.br/bibliotecacatalogo.html?view=detalhes\&id=225477> Acesso em: 08/02/2016.

${ }^{30}$ ROMERO, Sílvio. Op. cit., 1953, Tomo 1. p. 85.

${ }^{31}$ ROMERO, Ślvio. Op. Cit., 1953, tomo 3, p. 100.
} 
Silvio Romero ${ }^{32}$, mas assinalar que o crítico literário leu a formação brasileira e sua literatura a partir das "raças" que compuseram o país. É o que torna compreensível a percepção de Romero, para quem Machado seria "um brasileiro de regra, um nítido exemplar dessa sub-raça americana ${ }^{33}$ ”. Para Romero, Machado recusava a luta. A saber, a luta em defesa da nacionalidade e do progresso, os dois grandes pilares políticos e intelectuais do século XIX em todo Ocidente, pilares que Romero assumia como destino.

Não importa isto uma aprovação a certos absenteísmos muito do gosto dos ânimos fracos, que entendem de salvaguardar a própria pureza, fugindo sistematicamente das tentações. É proceder que nunca aplaudiremos. A virtude prova-se no meio da luta. A sociedade não é um convento de monjas. Que grande mérito advém em não se cobrir do pó a quem não sai à liça do combate e deixa-se tranquilamente ficar em doce e sossegado aposento? Devemos todos, homens de letras ou não, interessar-nos pelas pugnas e pelas dores da pátria ${ }^{34}$.

O "absenteísta" Machado, para desgosto de Romero, recusou solene e silenciosamente o discurso racialista e cientificista. Precisamente por isso, não se viu compelido a proferir qualquer formulação depreciativa sobre negros, índios e mestiços. Em sua obra literária Machado de Assis preferiu recusar a retórica oitocentista do progresso (e da ciência), do nacionalismo (e de suas racializações), o que implicou em recusar o realismo e o naturalismo pelos quais militava jovens de "A Nova Geração" (1879). As opções machadianas divergiam profundamente dos ideais romerianos. Mais que isso, a criticava severa e silenciosamente. O próprio Romero deixou evidente, na História da Literatura Brasileira (1888) seus compromissos políticos com a modernidade oitocentista, manifesto em sua adesão ao princípio da nacionalidade, bem como no que poderíamos de chamar de modernidade epistemológica, pa-

\footnotetext{
${ }^{32}$ Sobre uma análise global da obra de Silvio Romero, ver: VENTURA. Roberto. O estilo tropical: história intelectual e polêmica literária no Brasil (1870-1914). São Paulo: Companhia das Letras, 1991; SCHNEIDER, Alberto Luiz. Sílvio Romero, hermeneuta do Brasil... Op. Cit., 2005; FILHO, Cícero João da Costa. No limiar das raças: Silvio Romero (1870-1914). 2013. Tese (Doutorado em História Social). Faculdade de Filosofia, Letras e Ciências Humanas, Universidade de São Paulo, São Paulo, 2013.

${ }^{33}$ ROMERO, Sílvio. Machado de Assis: estudo comparativo de literatura brasileira [1897]. Campinas: Editora da UNICAMP, 1992. p. 66-67.

${ }^{34}$ ROMERO, Sílvio. Idem, p. 153.
} 
tente na adesão ao cientificismo evolucionista e naturalista, fundado no princípio da objetividade.

Se me faltou o talento, resta-me, em todo o caso, a face moral da empresa; a verdade e o patriotismo foram meus guias (...). Independência literária, independência científica, reforço da independência política do Brasil, eis o sonho de minha vida. Sejam eles a tríplice empresa do futuro. Tenhamos confiança ${ }^{35}$ !

Pretendo escrever um trabalho naturalista sobre a história da literatura brasileira. Munido do critério popular e étnico para explicar o nosso caráter nacional, não esquecerei o critério positivo e evolucionista da nova filosofia social, quando tratar de notar as relações do Brasil com a humanidade em geral. (...) Esta obra contém duas partes bem distintas; no primeiro livro indicam-se os elementos de uma história natural de nossas letras; estudam-se as condições de nosso determinismo literário, as aplicações da geologia e da biologia ${ }^{36}$, as criações do espírito ${ }^{37}$.

O sentido político e histórico da modernidade de Silvio Romero esteve na reposição da desigualdade, ou melhor, na modernização do princípio da desigualdade. Na medida em que o escravismo declinava e se instaurava a igualdade jurídica, a penetração do ideário científico da raça (ou na linguagem romeriana, a aplicação do "critério étnico" e "evolutivo") resguardado pela autoridade universalizante da ciência, repunha a desigualdade, que agora não mais se encontrava circunscrita à esfera da lei, mas inscrita no corpo e na "raça", na "biologia", diria Romero. Como mostra o antropólogo Louis Dumont, o racismo científico emergiu, nas últimas décadas do século XIX, justamente quando as hierarquias de classe enfrentavam a emergência de ideários igualitários, que apostavam na educação e na cultura como reversão da desigualdade de nascimento ${ }^{38}$.

\footnotetext{
${ }^{35}$ ROMERO, Sílvio. Op. Cit., 1953,p. 48.

${ }^{36}$ Grifo nosso.

${ }^{37}$ ROMERO, Ś́lvio. História da literatura brasileira... Op. Cit., p. 58-59.

${ }^{38}$ Ver DUMONT, Louis, Homo Hierarchicus. São Paulo: Edusp. 1992.
} 
Machado foi uma espécie de anti-Romero. Aliás, com alguma licença poética, podemos afirmar que Machado transformou Romero em personagem, uma espécie de Simão Bacamarte ${ }^{39}$. Romero, ao contrário da acusação de que não teria compreendido Machado, entendeu como poucos o sentido crítico embutido na crítica machadiana, por isso mesmo defendeu sua própria obra, atacando o escritor fluminense em Machado de Assis: estudo comparativo de literatura brasileira (1897). Romero percebeu com notável perspicácia as recusas do escritor: "[Machado] não é da raça dos humanitários propagandistas e evangelizadores de povos ao gosto de Tolstoi. É, a meu ver, uma espécie de moralista complacente e doce, eivado de certa dose de contida ironia ${ }^{40}$ ". O crítico não perdoava no escritor o suposto desinteresse pelas grandes conquistas do mundo moderno, nem aceitava a sua (suposta) falta de entusiasmo pelo país: "Por tudo dizer sem mais rodeios: Machado de Assis é bom quando faz narrativa sóbria, elegante, lírica dos fatos que inventou ou copiou da realidade; é quase mau quando se mete a filósofo pessimista e a sujeito caprichosamente engraçado ${ }^{41}$ ".

Para Romero, a experiência brasileira não pedia narrativa sóbria, elegante ou lírica à maneira de Machado de Assis, mas crítica, moderna e científica, a fim de pôr o país no caminho da modernidade ocidental; o atraso nacional não justificava um pessimismo elegante do Bruxo de Cosme Velho, mas otimismo mobilizador das forças, para viabilizar a abolição, sem desestruturar a produção, e encaminhar a imigração europeia sem desfigurar a nacionalidade brasileira. O atraso e a pobreza não autorizava o humour de Machado, mas espanto ou a ira, em favor do progresso e da ação ${ }^{42}$.

\footnotetext{
${ }^{39}$ Simão Bacamarte é o cientista, personagem principal do Alienista (1882).

${ }^{40}$ ROMERO, Sílvio, Machado de Assis: estudo comparativo de literatura brasileira... Op. Cit., p. 318.

${ }^{41}$ Idem, p. 320.

${ }^{42} \mathrm{O}$ ideal de progresso foi caro a Silvio Romero e os Estados Unidos pareceu-lhe a encarnação da "prosperidade". Embora o presente artigo se ocupe fundamentalmente da década 1880 e, menor grau, 1890, vale citar uma passagem de 1911, em que o velho Silvio Romero reitera de modo claro e loquaz a perspectiva liberal de progresso e a simpatia em ralação aos Estados unidos. "Em se tratando de prosperidade de um país qualquer, quando se afirma que esse país avança a passos largos na direção de amplo futuro, ocorre logo, ao espírito do que se ouve, que nessa terra se abriram novas e fecundas fontes de prosperidade, surgiram indústrias que não existiam; que o povo, disciplinado no trabalho, multiplica as colheitas, impulsiona a produção, acumula a riqueza;
} 
Por tudo isso, podemos afirmar que Silvio Romero foi um dos mais importantes operadores da modernização liberal, conservadora e republicana. Não operava mais no velho binômio senhores e escravos, pois o escravismo terminara, mas sob uma nova agenda: a oposição de matriz racial entre brancos (imigrantes) e negros. Debate moderno que haveria de ter continuidade no Brasil que viria.

\section{Fontes e Referências Bibliográficas}

\section{Fontes de época:}

ASSIS, Machado de; COUTINHO, Afrânio (org). "Instinto da nacionalidade". In: Machado de Assis - obra completa em três volumes. Vol III. Rio de Janeiro: Nova Aguilar, 1994.

."A nova geração". In: Machado de Assis - obra completa em três volumes. Vol III. Rio de Janeiro: Nova Aguilar, 1994.

"Dom Casmurro". In: Machado de Assis - obra completa em três volumes.

Vol I. Rio de Janeiro: Nova Aguilar, 1994.

. "Quincas Borba". In: Machado de Assis - obra completa em três volumes.

Vol I. Rio de Janeiro: Nova Aguilar, 1994.

. "O Espelho". In: Machado de Assis - obra completa em três volumes. Vol II.

Rio de Janeiro: Nova Aguilar, 1994.

" "Memórias Póstumas de Brás Cubas". In: Machado de Assis - obra completa em três volumes. Vol I. Rio de Janeiro: Nova Aguilar, 1994.

ROMERO, Silvio. História da literatura brasileira. tomo 1. Rio de Janeiro: José Olympio, 1953.

. Cantos do fim do século. Rio de Janeiro: Tipografia Fluminense, 1878.

. "Mensagens dos homens de letras do Rio de Janeiro ao governo provisório da República do Brasil". In. ROMERO, Sílvio. Novos estudos de

que o capital cresce e se avoluma; como se vê a população inteira na faina; nota-se uma espécie de consensus, de harmonia em todas as classes de alto a baixo e por todos os recantos do território (...). Ninguém se lembra de indagar o que faz o governo. Sabe-se, de antemão, que, nestas terras privilegiadas do trabalho, ele se limita a deixar sem peias as forças propulsoras da nação". ROMERO, Silvio. Estudos sociais: o Brasil na primeira década do XX. Lisboa: Mala da Europa, 1911. p. 199. 
Literatura. Rio de Janeiro: Garnier, 1898.

. Machado de Assis: estudo comparativo de literatura brasileira. Campinas: Ed. da Unicamp, 1992.

. "A questão do dia - a emancipação dos escravos". Rio de Janeiro: Revista Brasileira, 1881.

. "Sobre Machado de Assis e Luís Delfino". In: Estudos de literatura contemporânea. Rio de Janeiro: Laemmert, 1885.

. Provocações e debates: contribuições para o estudo do Brasil social. Porto: Lello.

\section{Bibliografia Geral}

ALENCASTRO, Luiz Felipe de; RENAUX, Maria Luiza. "Caras e modos dos migrantes e imigrantes". In: ALENCASTRO, Luiz Felipe de (org.). História da vida privada no Brasil: Império. Coordenador-geral da coleção: Fernando A. Novais. São Paulo: Companhia das Letras, 1997.

ALONSO, Angela. Flores, Votos e Balas: O Movimento Abolicionista Brasileiro (1868-1888). São Paulo: Companhia das Letras, 2016.

Ideias em Movimento: A geração 1870 na crise do Brasil-Império. São Paulo: Paz e Terra, 2002, p. 332.

"Joaquim Nabuco e os abolicionistas britânicos. Correspondência, 1880-1905”. Estudos Avançados. Vol. 23, No. 65, São Paulo, 2009.

ANDERSON, Benedict. Nação e consciência nacional. São Paulo: Ática, 1989.

AZEvEDO, Celia Maria Marinho de. Onda negra, medo branco. São Paulo: Annablume, 2015.

AZEVEDO, Elciene. O direito dos escravos. Lutas jurídicas e abolicionismo em São Paulo. Campinas: Editora da Unicamp, 2010.

. “Se negro sou, ou sou bode, pouco importa, o que isso pode?': inclusão e cidadania na pena de Luiz Gama". In: Pensadores negros - pensadoras negras; Brasil, séculos XIX e XX. Rio de Janeiro / Belo Horizonte: MC\&G Editorial / Editora Fino Traço, 2016.

BOURDIEU, Pierre. A economia das trocas simbólicas. São Paulo: Perspectiva, 1974.

BARRETO, Luiz Antonio (org). Literatura, história e crítica, Rio de Janeiro: Imago, 1992. 
CAMPOS, Gustavo Barreto de. Dois séculos de imigração no Brasil: A construção da imagem e papel social dos estrangeiros pela imprensa entre 1808 e 2015. Tese de Doutorado em Comunicação e Cultura. UFRJ, 2015.

CÂADIDO, Antônio. O método crítico de Silvio Romero. São Paulo: Ed. da USP, 1963.

. Esquema de Machado de Assis. In: Vários Escritos. São Paulo: Duas Cidades, 1995.

CARVALHO, Maria Alice Rezende de. O quinto século, André Rebouças e a construção do Brasil. Rio de Janeiro: Revan / Iuperj, 1998.

CARNEIRO, Maria Luiza Tucci; CROGI, Frederico; FRANZINA, Emilio (organizadores). História do Trabalho e Histórias da Imigração: Trabalhadores Italianos e Sindicatos no Brasil (Séculos XIX e XX). São Paulo: Editora da Universidade de São Paulo: Fapesp, 2010.

CHALHOUB, Sidney. Machado de Assis, Historiador. São Paulo: Companhia das Letras, 2003.

FILHO, Cícero João da Costa. No limiar das raças: Silvio Romero (1870-1914). Tese (Doutorado em História Social). FFLCH. USP, 2013.

FUENTES, Carlos. Machado de la Mancha. México: Fondo de Cultura Económica, 2001.

GELLNER, Ernest. Naç̃̃es e nacionalismo. Lisboa: Gradiva, 1993.

GLEDSON, John. Machado de Assis: imposturas e realismos. São Paulo: Companhia das Letras, 2005.

GUIMARÃES, Hélio Seixas Guimarães. Romero, Araripe, Veríssimo e a recepção crítica do romance machadiano. Revista Estudos Avançados vol. 18, 51, p. 269-298, 2004.

. Sobre a recepção mais ampla de Machado, in. Hélio Seixas Guimarães, Os leitores de Machado de Assis. São Paulo: Nankin / EDUSP, 2012.

HARTOG, François. "Memória, história e presente". In Regimes de historicidade: presentismo e experiências do tempo. Belo Horizonte: Autêntica editorial, 2013. pp. 133-191.

HAWKINS, Mike. Social Darwinism in European and American Thought 18601945 - Nature as a Model and Nature as a Threat. Cambridge: Cambridge University Press, 1998

HOBSBAWM, Eric J. Nações e nacionalismo. Rio de Janeiro: Paz e Terra, 1990. 
HOLANDA, Sérgio Buarque de. "Silvio Romero". In O espirito e a letra: estudo de crítica literária, II. São Paulo: Companhia das Letras, 1996.

LOTIERZO, Tatiana. Os contornos do (in) visivel: A Redenção de Cam', racismo e estética na pintura brasileira do último Oitocentos. Dissertação de Mestrado. Antropologia Social. FFLCH-USP, 2013.

MACHADO NETO, Antônio Luís. Estrutura social da República das letras: sociologia da vida intelectual brasileira (1870-1930). São Paulo: Edusp, 1973.

MEGID, Daniele Maria. À roda de Brás Cubas: literatura, ciência e personagens femininas em Machado de Assis. Mestrado em História. Campinas: IFCH UNICAMP, 2012.

MATTOS, Ilmar Rohloff de. O Tempo Saquarema. 5 a edição, São Paulo: Editora Hucitec, 2004.

. "Construtores e Herdeiros. A trama dos interesses na construção da unidade política". In: Almanack Braziliense, São Paulo, v. 1, n. 1, p. 8-26, 2005.

MEGID, Daniele Maria. À roda de Brás Cubas: literatura, ciência e personagens femininas em Machado de Assis. Mestrado em História. Campinas: IFCH UNICAMP, 2012.

NABUCO, Joaquim. O Abolicionimo. Rio de Janeiro: Nova Fronteira, 1999.

NEEDELL, Jeffrey D. Belle époque tropical: sociedade e cultura de elite no Rio de Janeiro na virada do século. São Paulo: Companhia da Letras, 1993.

PAZ, Francisco Moraes. Na poética da história: a realização da utopia nacional oitocentista. Curitiba: Editora da UFPR, 1996.

PINTO, Ana Flávia Magalhães. Fortes laços em linhas rotas: literatos negros, racismo e cidadania na segunda metade do Século XIX. Tese (Doutorado em História)IFCH / Unicamp. Campinas/SP, 2014.

PINTO, Ana Flávia Magalhães. "José do Patrocínio: abolição, racismo e uma pedra no caminho chamada Sílvio Romero". In: CHALHOUB. Sidney; PINTO, Ana Flávia Magalhães. (Org.). Pensadores negros - pensadoras negras; Brasil, séculos XIX e XX. Rio de Janeiro; Belo Horizonte: MC\&G Editorial; Editora Fino Traço, 2016.

REBOUÇAS, André. Diários e Notas Autobiográficas. Rio de Janeiro: José Olympio, 1938.

ROCHA, João Cezar de Castro. À roda de Machado de Assis: ficção, crônica e crítica. Chapecó: Argos, 2006. 
. "O ruído das festas" e a fecundidade dos erros: como e por que reler Silvio Romero. Tempo Brasileiro: Repensando o Brasil com Silvio Romero. Rio de Janeiro, n. 145, abr./jun. 2001.

SANTOS, Sydney dos. André Rebouças e seu tempo. Rio de Janeiro: Vozes 1985.

SILVA, Alberto da Costa e Castro Alves: um poeta sempre jovem. São Paulo: Companhia das Letras, 2006.

SILVEIRA, Daniela Magalhães da. Fábrica de Contos: ciência e literatura em Machado de Assis. Campinas, SP: Editora da Unicamp, 2010.

SCHNEIDER, Alberto Luiz. Silvio Romero hermeneuta do Brasil. São Paulo: Annablume, 2005.

. "O Brasil de Sílvio Romero: uma leitura da população brasileira no final do século XIX”. Projeto História, no 42. Junho de 2011.

. "Sílvio Romero e Machado de Assis: leituras e dissensos do fim do Oitocentos". Intelligere: revista de História Intelectual. USP, v. 2, p. 49, 2016.

SCHWARZ, Roberto. Um mestre na periferia do capitalismo: Machado de Assis. 2 ed. São Paulo: Duas Cidades, 1991.

. Ao Vencedor as Batatas: Forma literária e processo social nos inícios do romance brasileiro. São Paulo: Duas Cidades, 1977.

. "A viravolta machadiana". In Martinha versus Lucrécia. São Paulo: Companhia das Letras, 2012

SEVCENKO, Nicolau. Literatura como missão: tensões sociais e criação cultural na Primeira República. São Paulo: Brasiliense, 1985.

SKIDMORE, Thomas E. Preto no branco: raça e nacionalidade no pensamento brasileiro. Rio de Janeiro: Paz e Terra, 1976.

THIESSE, Anne-Marie. A criação das identidades nacionais. Lisboa: Temas e debates, 2000.

TRINDADE, Alexandro Dantas. André Rebouças: da Engenharia Civil à Engenharia Social. Tese (Doutorado em Ciências Sociais). Campinas/SP: IFGH -UNICAMP, 2004.

TRINDADE, Joyce Nathália de Souza. Fosé de Alencar e a escravidão: necessidade nacional e benfeitoria senhorial. Dissertação de Mestrado. Programa de PósGraduação em Ciências Sociais da UNIFESP, 2014. 
VENTURA, Roberto. O estilo tropical: história intelectual e polêmica literária no Brasil (1870-1914). São Paulo: Companhia das Letras, 1991.

ZILBERMAN, Regina. "Entre duas histórias: de Silvio Romero e José Veríssimo". In: ROCHA, João Cezar de Castro (org). Nenhum Brasil existe: pequena enciclopédia. Rio de Janeiro: UniverCidade \& Topbooks, 2003.

\section{Imagens}

A Redenção de Cam. In: ENCICLOPÉDIA Itaú Cultural de Arte e Cultura Brasileiras. São Paulo: Itaú Cultural, 2017. Disponível em: <http://enciclopedia.itaucultural.org.br/obra3281/a-redencao-de-cam>. Acesso em: 31 de Ago. 2017. Verbete da Enciclopédia.

Retrato de André Rebouças. In: Museu Histórico Nacional. Disponível em: <http://www.museuhistoriconacional.com.br/images/galerial1/mhg1la029.htm>. Acesso em: 31 de Ago. 2017.

Retrato de Machado de Assis. In: Academia Brasileira de Letras. Disponível em: <http://www.academia.org.br/a-historia-da-abl/a-lideranca-de -machado-de-assis>. Acesso em: 31 de Ago. 2017.

Retrato de Silvio Romero. In: Academia Brasileira de Letras. Disponível em: <http://www.academia.org.br/academicos/silvio-romero>. Acesso em: 31 de Ago. 2017.

Retrato de José do Patrocínio. In: Academia Brasileira de Letras. Disponível em: <http://www.academia.org.br/academicos/jose-do-patrocinio/ biografia>. Acesso em: 31 de Ago. 2017.

Retrato de Joaquim Nabuco. In: Academia Brasileira de Letras. Disponível em: <http://www.academia.org.br/academicos/joaquim-nabuco>. Acesso em: 31 de Ago. 2017.

Recebido: 01/02/2017 - Aprovado: 11/09/2017 